\title{
THE COMPLEX DYNAMICS OF LAND IN MIGRANT LABOUR SOCIETIES: WHO NEEDS LAND FOR AGRICULTURE?
}

\begin{abstract}
Vusilizwe Thebe
Department of Anthropology and Archaeology, University of Pretoria, Pretoria, South Africa

E-mail: vusi.thebe@up.ac.za

Citation: Thebe, V. 2018. The complex dynamics of land in migrant labour societies: Who needs land for agriculture?. J. Asian Rur. Stud. 2(2): 132-143

Abstract: The agricultural modernisation narrative has been a central assumption of rural development since the mid-twentieth century, and more recently, the land reforms currently underway in Southern Africa. The narrative emphasises the viable use of land, defined in this case through agricultural productivity and market oriented production. The main contention of this paper is that such a focus undermines the rural socio-economic structure inherent in certain rural societies, which emerge through negotiations and compromises as societies change. It draws on data from studies in Lesotho and rural Zimbabwe that shows that rural households do not only hold land for agricultural purposes, but would hold onto land for security beyond mere agriculture production. It particularly emphasises the complex relationship between households and land, complex land needs and landholding patterns. As way of conclusion, it cautions against enforcing a peasant path on rural society through agriculture-based interventions.
\end{abstract}

Keywords: agriculture; land; Lesotho; migrant labour societies; Zimbabwe

\section{Introduction}

Why do rural households need land? Potts and Mutambirwa (1990) once asked a similar question in relation to labour migrants during the early years of Zimbabwe's independence. They asked this question as an implicit response to what many saw (at the time) as Zimbabwe's 'official policy of ending "divided families" by pushing some [people] into being unambiguously working class families with no land and others into a settled, non-migratory peasantry' in the early 1980s' (Bush \& Cliffe, 1986, p. 77). As a response to the question, their conclusion was that the decision by labour migrants to hold onto rural land was largely dictated by security concerns - 'security against unemployment or failure of their urban enterprise and, most importantly, old age or disability' (Potts \& Mutambirwa 1990, p. 698).

Yet, the agricultural modernisation narrative, which has been a central assumption of rural development policy and land reform in southern Africa since the mid-twentieth century, emphasises the viability of land in terms of agricultural production. As has been observed: This narrative has often come to define understandings of agricultural development in Africa in relation to technology (and a shift from 'backward' to 'modern' practices), markets (and a shift from self-provisioning to market-based production and consumption), and economic productivity and growth (and a shift from 'subsistence' to commercial farming) (Cousins \& Scoones, 2010, pp. 33 - 34). 
Implicit in this narrative is the perception that land available to households can be used more efficiently and productively if households are transformed into a class of 'yeomen' farmers, operating small farm units. The narrative has underpinned rural development interventions in settler southern Africa and continues to dictate government policy on agriculture in Zimbabwe as demonstrated by early attempts at internal resettlements (to reorganise land use in Communal Areas) and the resettlement models adopted after independence (Alexander, 1994; Chaumba et al., 2003; O'Flaherty, 1998).

Hence, the importance of my main question: to what extent are social realities being taken into account as rural development packages are promoted and implemented? This article explores the way that rural households utilise land to construct livelihoods and ensure survival in Lesotho and Zimbabwe. In particular, it focuses on how households' land strategies have been moving away from agriculture and more into non-farm livelihoods, which are less risky and rather secure.

\section{Methods}

Drawing on studies conducted in north-western Zimbabwe and Lesotho, the article explores households' behaviour towards land. The studies consisted primarily of surveys and ethnographic enquiries of social dynamics, and households' practices by a group of post-graduate students who have since produced dissertations and theses, and my own research in Lesotho and a study that has span over a decade in north-western Zimbabwe.

In the Lesotho case, the study conducted a year-long study on 230 peri-urban households situated in southern Maseru in 2012. The focused on household case histories on the dynamics of land and how land is valued. It also drew selectively on studies on agrarian transition by students conducted in the same localities. In Zimbabwe, the study drew data largely from a broad project that has span over 15 years and is still on-going. This extended study focused mainly on how worker-peasants have interacted with government policies, and also sought to understand their relationship to land and agriculture.

\section{Results and Discussion}

\subsection{Migrant labour societies in Zimbabwe and Lesotho}

To help us to understand migrant labour societies in Zimbabwe and Lesotho, it is useful to distinguish them from other types of societies. Ray Bush and Lionel Cliffe provide this distinction in their 1984 essay:

It is now commonplace to characterise the societies of southern Africa as 'labour reserve economies'. Rural areas reserved for Africans are in no sense still 'traditional', but provide for the reproduction of labour power, used elsewhere in the economy in capitalist production, on terms that make it available especially cheaply as some form of migrant labour. This essential relationship gives rise to the well-known phenomena of the 'worker-peasant' and of 'split families' (Bush \& Cliffe, 1984, p. 77). 
A similar emphasis on 'split families' appeared in Cordell et al., (1996)'s analysis of circular migration regimes in West Africa, where the rural economy was defined by combinations of hoe and wage. With specific reference to southern Africa, Henry Bernstein also conceptualized migrant labour societies in terms of 'combinations of wage and hoe' or of 'farming and migrant labour', and made reference to the 'distinctive historical lineages ...flagged by ideas, and debates about "worker-peasants"" (Bernstein, 2004, p. 212). He thus, observed:

This is a vast area of issues with its own complexities and contentions represented in a rich empirical and analytical literature which, inter alia, prefigures the more general thesis of the 'fragmentation' of labour in contemporary 'globalization', stated so baldly above. Such conventional and pervasive distinctions/separations as 'urban' and 'rural', 'worker' and 'farmer', are blurred by the social logic of migratory labour systems.

This fragmentation of labour thesis acknowledges the coexistence of land-based livelihoods and labour migration, each being important to livelihood security and survival of rural households; and in the process, the entrenchment of these systems in the social system (O'Flaherty, 1998). This is the logical result of a system, which according to Potts $(2000$, p. 807) was predicated on migrants retaining rights to rural land'. A key feature of such societies is the out-migration of men. In the words of Boehm $(2003$, p. 5) '[m]en were and are supposed to make money'.

On this view, because labour migrant men spend most of the time away from the rural space and their households have income security from elsewhere, agriculture remains a part-time activity since there is little incentive to farm productively. For example, in Lesotho 'labour migration brought substantial incomes to rural economies' in the 1970s that farming came to be seen as a low status and feminine activity performed by women (Boehm, 2003, p. 5).

In Zimbabwe, Pius Nyambara also portrayed labour migrants as part-time farmers who 'book' rural land by leaving wives and children while they take up jobs in the cities (Nyambara, 2001). He attributed this to the 'flexibility of the communal tenure system, which rural households exploited in order to combine both rural and urban incomes. In a way, this seems to suggest that labour migrant households are inefficient in their utilisation of land since they lack labour, experience, expertise and commitment (see, e.g., Hughes, 1974).

Clearly, a worker-peasantry continues to exist in former migrant labour societies in southern Africa. In Lesotho, where agriculture is cash intensive, its practice and success has remained 'highly dependent on migrant labour' (Boehm, 2003, p. 5). In Zimbabwe, some post-independence studies have shown that labour migrants choose to hold onto land despite opportunities to remain in town permanently (Potts \& Mutambirwa, 1990); others have also emphasised the role of the wage on agriculture and social status (Coudere \& Marijsse, 1988; Weiner \& Harris, 1991). As others have noted, households have taken advantage of communal tenure arrangements and adapted the tenure system to accommodate the coexistence of subsistence farming and migrant labour (e.g. Nyambara, 2001, O'Flaherty, 1998). 


\subsection{Land and the Dominant Tenure System in Lesotho and Zimbabwe}

\subsubsection{Land rights and land allocation}

In both countries tenure relations in rural areas, where the majority of the population is found, are viewed as communal: land being common property that is a life-long although not exclusive entitlement (O'Flaherty, 1998; Pule \& Thabane, 2004). A key feature in land rights and holding under such systems is usufruct, where rights to land are conferred on the basis of need and such rights are not transferable. When, after a period of use, and if the one with land rights has no further use of such land, it reverts to the common pool and is available for reallocation.

Associated with the conferment of land rights is authority over land matters. In such 'traditional' tenure systems, traditional institutions (the institution of the chief and headmen) are often charged with conferring land rights for both residence and fields and rights to the commons. In these societies, rights to the residential plot are considered exclusive, but land allocated for fields is often released to the commons after harvest.

The chieftainship institution (through the office of the Chief or the bureaucratised sub-chief) had the authority over land: chiefs or the sub-chiefs (at least in Zimbabwe) had an administrative role in land matters, and was seen as key in allocating land for agricultural, residential, or any other reason (Cheater, 1990; Pule \& Thabane, 2004).

In Lesotho, the chieftainship institution drew its authority over land from the Laws of Lerotholi, which was the customary law governing land tenure in Lesotho (Mphale et al., 2002). These laws, which were promulgated in 1903, remain the basis through which customary land tenure originated. They give chiefs the powers to allocate land in their area of jurisdiction to all their subjects fairly and impartially.

In Zimbabwean rural areas, the traditional institution derived its power from the colonial system of indirect rule, which carved traditional political structures of administration throughout the country after colonial conquest (O'Flaherty, 1998; Ranger, 1982). One of the main achievements of the colonial administration was the bureaucratisation of traditional leadership by recasting of the office of the sub-chief as subhuku (to maintain the tax register). Michael O'Flaherty related this process to the communal land tenure system:

The bhuku, as an administrative instrument, was itself a potent force in the shaping of land tenure systems in Zimbabwe. The more strict formalisation of (traditional) corporate control over land was perhaps a side effect of the colonial administration's attempt to gain control over people for tax purposes. However, the elaboration of the traditional political system and the current strength of traditional leaders derived principally from their role in regulating access to arable land (O'Flaherty, 1998, p. 543).

Land rights were determined through community membership, which also implied recognition of the allocating authority by those who, by law, have rights to occupy the land (Cheater, 1990; Sperfeld 2006). In principle, once land was allocated, the landholder retained usufruct rights, and relinquished such rights when he/she no longer had any use for the land (Cheater, 1990; Pule \& Thabane, 2004). Underpinned by an ideology of communalism, households had exclusive rights to residential plots, crops produced and other produce, but such rights did not extend to the fields, which were released to the common pool after harvest. 


\subsubsection{Politics in land allocation}

Generally, the traditional institution, particularly the chieftainship institution in Lesotho and the office of the sub-chief (sabhuku) in Zimbabwe, assumed absolute power over land allocation (O'Flaherty, 1998; Pule \& Thabane, 2004). To this day, the post-independence state in Lesotho and Zimbabwe has made numerous attempts to wrestle control over land allocation away from traditional leaders and confer it on elected bodies (Cheater, 1990; O'Flaherty, 1998; Wittmayer, 2007).

For Lesotho, the government introduced elected bodies as political institutions to assist and advise chiefs in land governance after independence, and used the reforms to neutralise the power of the chiefs in land allocation (Quinlan, 1983). In the 1970s the government embarked on a number of reforms, starting with the enactment of the Land Act of 1973, Land Husbandry Act (1973) and the Land Administration Act (1973) and consolidated these into the Land Act of 1979, which were meant to create efficiency in land governance and administration in the country.

Similarly, in Zimbabwe the Communal Land Act of 1982 (which governs how land is to be allocated in Communal Areas) was designed to curtail the power of the chiefs (and their headmen) in land governance matters. In fact, the act reduced the power and role of the chiefs in their communities and transferred land related responsibilities to elected councils. As O'Flaherty (1998, pp. 539-540) notes:

'traditional' leaders are not authorised by the Act to resolve disputes centred on land, as this right is the prerogative of District Councils, as specified in the Communal Land Act. Land and all unimproved resources on it are held in trust for Communal Area residents by local government, that is, District Councils.

\subsubsection{Landholding: theory vs practice}

Communal landholding has varied by location and time, but adjusted deviations from the 'ideal' model have been evident across time periods and geographical locations (Cheater, 1990; Pule and Thabane, 2004). Striking similarities exist in terms of the contradiction between theory and practice between Lesotho and Zimbabwe, for example, where the communal tenure system has proven to be highly flexible (Cheater, 1990; Nyambara, 2001; Pule \& Thabane, 2004). The landholding patterns in Lesotho and Zimbabwe are such that land allocated to a household is treated as private property (Cheater, 1990; Pule \& Thabane, 2004; Thebe, 2012). In most cases, households find it necessary to protect the land they hold against public use (Thebe, 2012).

In the Zimbabwean case, the flexibility of the communal tenure system is tied to the development of labour reserves, where land was allocated with an allowance for future expansion. Many have emphasised the attraction of 'makombo' (defined in term of abundant land) and the prospects of 'tema madiro' (unrestricted land clearances) (Chimhowu \& Hulme, 2006). It was this setting, yet, significantly, contextualised by an ambiguous land tenure system, that set the scene for negotiation and exploitation of the land tenure system by households in both countries.

\subsection{The Lesotho case study: Mazenod in peri-urban Maseru, Lesotho}

The Mazenod area is one of the areas in peri-urban Lesotho that has experienced phenomenal growth in recent times. The area is broadly typical of semi-urban settlements in Lesotho, combining elements of rurality including clandestine settlements 
and fields, with modernity, characterised in this case by modern infrastructure including modern housing and connecting roads; livelihoods; high household population density; and homes that sometimes share fences. According to the 2006 population and housing census, Mazenod had a population of 8167 people and 2005 households.

What is of interest here is that households in Mazenod once held and some still hold land rights (in the form of fields) in areas now under the jurisdiction of the Korokoro Community Council, and that some settlements in Ha Nko and Airport Area resulted from land sales by landholders in the Mazenod section. Thus, we can categorise households in Mazenod as indigenous and those in the former as settlers. This also means that indigenous households' landholdings extended beyond the residential plot, while for settler households, land rights depended on the quantity of land actually purchased. Some had purchased large pieces of land, but others had purchased smaller pieces for residence.

In Lesotho, land rights can be held through allocations, licences and leases as provided for by the Land Act of 1979, but prior to the Act, access to rural land was guided by customary law. The chief was the custodian of the land. In Mazenod households that I refer to as indigenous, acquired land rights through initial allocation by the Thota-Moli chieftaincy. In principle then, the households that were allocated land by the chief only retained usufruct rights although they could obtain life interest on the land. Such land could not be disposed of in any way.

However, in practice vernacular land sales and leases were clearly in operation as households had freely engaged in land transactions: either through fission to sons and relatives or outright sales. With the land disposed and then utilised for settlement, agricultural land increasingly gave way to settlements, moreso since the new landholders assumed complete rights to the land, and in-turn, they were free to dispose of such land. For this to happen, the initial landholder needed to convert the initial Form $\mathrm{C}$ certificate issued for the land into a lease by applying to the Commissioner of Land.

In the study of 230 households, 108 were indigenous households, 84 were settler households that acquired land from the former, and 38 had benefited from the fission of land. Of the 122 settler households, 54\% had also participated in land sales, redistribution or leases. The estimated year in which land sales began in Mazenod is 1986 when only $3 \%$ of initial landholders in the study sold part of their fields in $\mathrm{Ha}$ Nko. By the year 2000, the proportion of landholders that had sold land had risen to $25 \%$, and in 2005, they had risen to over $33 \%$. In 2010, nearly all landholders that had land rights in Ha Nko had parcelled out their fields, and others had sold whole fields.

\subsection{The Lupane Case Study: A former 'native' reserve in the 'dark gusu' forest of Matabeleland}

The second case study area, southe-western Lupane District on the southern fringes of the former Shangani Reserves, is about $180 \mathrm{~km}$ from Bulawayo City along the A8 Highway (northern road connecting Bulawayo to Zambia). The area now constitutes large parts of the Menyezwa Ward, under Chief Mabhikwa Khumalo. It was established around the late 1940s by Ndebele households that were evicted from 'white' land - land expropriated for commercial agriculture and mining - although these migrant groups found in the area some forest tribes (the sili) (Alexande et al., 2000). 
The Ndebele groups came from areas like Figtree, Insuza/Bubi, Inyathi and Nyamandlovu where capitalism had already taken root. Chief Menyezwa Gumede, for instance, arrived in the area from Figtree in 1948 and became chief of groups from Bubi/Insuza, Inyati and Nyamandlovu, and subsequent arrivals, especially in the postsettlement period, who came from other contested areas, particularly those in peri-urban Bulawayo.

From the 1950s onwards, these parts of the ' $g u s u$ ' frontier and other similar areas to the north, received even more people that were evicted from Filabusi, Fort Rixon and Matopo (Alexander et al., 2000). As noted elsewhere (Thebe, 2017), it is also possible that new arrivals in the 1950s and 1960s were referred for land in the reserves by early arrivals who were already established in the reserve region.

Of significance was the number of men who held jobs in the capitalist sector in Bulawayo, among those who established homes in these parts of the ' $g u s u$ ' frontier. The fact that these men never gave-up their jobs, and their families remained in the reserves suggests, as Nyambara (2001, p. 776) noted elsewhere, that their intention was merely to "book" land,.... by leaving their wives at the new location, and then returning to work'. The key point here is that the origin of settlers and the patterns of life they had established prior to their eviction left these parts of the ' $g u s u$ ' frontier dominated by a worker-peasantry, with interests both in rural land and the urban sector.

Primarily as a result of land availability, households could clear as much land as they could manage with no restrictions to the size of the plot (tema madiro). The allocation of land was the responsibility of the headmen who were often the lineage leaders of these groups. These allocated land to their people, and people outside their groups who enrolled into their villages. Initial plot sizes were big and land allocations had allowance for future expansion. Average farm land for households was around 5 hectares, more than an average household could cultivate in a single rain season, and extended households had even bigger land.

Contrary to the Lesotho case, this is a typical rural society - both in terms of geographical and social aspects - and households have guaranteed land access rights to residential plots, fields and commons. While fertile cultivatable land has become scarce in the recent past, land previously used for crop production and has been fallowed and released as pasture can always be revived and re-used by new households. However, complex land claims and rights patterns presented major challenges to land acquisition for new households, particularly in terms of developing settlements and cropland.

The key challenge associated with land access is that land is held and controlled by households that were allocated initial rights at first occupation. Though in principle land is controlled by the office of village head and allocated under 'communal' tenure, in practice rights to land are treated as if they are exclusive; households often refer to their land allotment as 'their land' (indawo yami) (Thebe, 2012, 2017).

Generally, a household allotted land by a headman, retained rights to the residential plot, fields and any arable land extending from the fields and residential plots, and once such land was allocated the headman relinquished any control over it. The landholder could leave the land fallow, clear additional cropland, but would still retain claims to such land including the arable land, which he reserved for future expansion.

This system sits alongside the emerging communal tenure system elsewhere in the reserves, where the tenure system has been adapted in line with the dominant 
livelihoods in society. With such land allocated and rights recognised by others, the landholder retained rights to allocate it to others in his family and even outsiders. For such allocations to be recognised, the headman must be informed so that the new landholder could be added to the village register, but no such process was required if such allocations were limited to cropland.

Major policy changes on rural land governance (including post-independence reforms in the form of the Communal Land Act of 1982 and the Traditional Leaders Act of 1998), although they transferred the authority over land to Rural District Councils appeared to have failed to alter landholding practices that were already in place.

The local council (the Kusile District Council in this case), appears not to have taken the trouble to exercise this right, allowing the village headmen to exercise this right on its behalf in consultation with the Village Assembly. Households continued to exercise and protect land rights, even in situations where land had been idle for long, which limited the land allocation responsibilities of headmen. On their part, headmen have only been content with settling new households on communal woodlots and land whose initial holders had relocated to other areas.

In this society sons have guaranteed rights to land, and households have taken advantage of society's recognition of such land rights to hold onto land they have fallowed on the understanding that the land would be settled on by sons in future. Landholders often argued:

There is no land that is idle.....land may lie unutilised now, but it does not mean it is not needed....tomorrow you may find settlements.... We all have sons that may need this land in future. They may not want it today, but what happens in future when they finally leave their work and have to return home for good? If there is no land for them.....they will go elsewhere, and what will happen to us who depends on their support? (Interview, Gwayi, December 2014)

The above quotation also shows how land has been used to keep families together, and also to guarantee that a household has the necessary support systems when the initial landholder has lost the capacity to work the land. This is one of the reasons why the communal tenure system remains the most suitable tenure system for rural households. Generally households' land allotments were such that there was often additional arable land that was not prepared for crop production. It was this land space that was often assigned to sons who wished to establish own homes.

Generally, households could register life-long interests on land, which allowed for land access through intergenerational succession. If a landholder died, the woman took over the land as the head of household and such land could be subdivided into individual landholdings by sons. Rather than an individual holding, land appeared to be a household asset, allocated to the household but often worked and managed on a dayto-day basis by the woman in the absence of the man who spent most of his time away at work.

Besides the right to transfer land rights, households could exercise the right of exclusion by preventing exploitation of resources from their land. Many households that held land managed to exclude other community members from all their land and not only cropland, which was often exclusive until harvest. While many of the households used this land as pasture, not all community members could graze their cattle. Only 
those neighbours that the household had close working relations had access to such land. For some households, these plots of land were fenced-off not only to prevent encroachment by animals, but also, to ensure that people did not poach resources like poles and thatching grass.

\subsection{Vernacular land markets}

As we have seen, land in these former reserves remained the property of the household. Despite the restrictions imposed on the households implied by the tenure arrangements, there was evidence that vernacular land markets were clearly at play. In addition to land parcels to household members, households were involved in various forms of land transactions including land allocations to outsiders, land leases and outright land sales (although rather informal).

Perhaps the most prominent of these land transactions were field leases by landholders to newly established households or others in the community that needed alternative land, may be land on different type of soils for the production of particular crops. In this category we might include households that had inherited land from kin households that relocated from the area, and those that struggled to put all their fields under cultivation. Here in these parts of the 'gusu' frontier, both categories of households were well represented

Another striking behaviour by landholders in this 'gusu' frontier - one that serves to remind us about the power of land in building networks and ensuring livelihood guarantees outside agriculture - was the allocation of land for settlement to outsiders by households. Apart from leasing cropping fields to neighbours, from to time, households with land to spare would settle relatives from other areas and sometimes complete strangers on their land.

These kinds of transactions, of course, were between the landholder and the prospective settler: the landholder placed the newcomer on his land and allocated him cropping fields. But once a landholder had decided to allocate land to an outsider, he would introduce the potential settler to the headmen and village assembly that would deliberate on such request, and once an agreement was reached to accept the newcomer, the new household was added to the village register. There was no further responsibility towards such a household by the headman or other households. Of course, such an individual could be leased land by another household for additional fields.

A related practice in these land transaction was the sale of land to people within the community. While the practice was not common because in the event that a household relocated from the area, the land was often taken over by kin remaining in the community. It was in fact only in rare circumstances where relocating households opted to sell their land rather than release it to kin, but these transaction were increasing with increased cross-border migration, and as a result, availability of income by young members of the community. Where they happened, many elements of these land transactions were similar throughout the community: land transactions were carried out in the pretext that the land buyer was compensating the landholder for the developments on the land like huts and fencing, yet the buyer would also inherit the fields and arable land. 


\section{Conclusion}

The evidence from the two cases draws attention to a spectrum of land strategies that different categories of households exercise for their livelihoods, which extend beyond agriculture, the production of crops and commercial agricultural entrepreneurship as has been the emphasis in the modernisation narrative. Households' ownership of land is intimately linked to the socio-cultural constructs in society that have been shaped by livelihoods experiences and encounters with the natural environment.

Households would use a variety of land strategies to negotiate the vulnerability associated with agriculture-based livelihoods and for secure and sustainable livelihoods through land. Land is thus still a major vehicle through which households secure their livelihoods outside agriculture. For households, land presents a set of rational strategies to livelihood security and the development of social capital. The livelihood patterns that have emerged overtime continue to guide the way in which households manipulate the communal tenure system to their advantage.

Land has proved useful here as a resource through which to examine how livelihoods are constructed, natured and secured as households negotiate their survival either through non-agriculture based activities or by developing different networks for livelihood security. If there is anything we can learn from the two cases, it is that individuals and groups will hold onto land (to quote Shipton \& Goheen, 1992, p. 307) for 'many purposes: not just to produce the material conditions of survival and enrichment, but also to gain control over others, and to define personal and social identities'.

Similar situations of negotiations happen in other rural communities, particularly as households continue to disengage from agriculture in the context of climate change. Thus, patterns of behaviour identified in this study are likely to be found in other migrant labour societies in the region where the land tenure system guides land access and holding for households. We can relate the evidence presented here to results from other post-independence studies in Zimbabwe, particularly Potts and Mutambirwa (1990)'s on labour migrants in Harare, which showed that rural land is an important form of security for urban migrants.

The two cases, however, should not be taken as being representative of all rural societies, and should be viewed from a specific socio-economic context and its historical foundations, which for reasons associated with the consolidation of capitalism in the region has survived post-colonial rural transformation processes. Nevertheless, the cases imply that interventions geared at developing "modern", and "progressive" farmers and farming' depart from the actual realities in some rural societies (Cousins \& Scoones, 2010, p. 33). A focus in developing small farming communities undermines the rural socio-economic structure that had emerged in the context of the semiproletarianisation of rural society and the emergence of 'combinations of wage and hoe' as processes of accumulation (Bernstein, 2004, p. 221). 


\section{References}

Alexander, J. (1994): State, peasantry and resettlement in Zimbabwe. Review of African Political Economy 61, 325-345.

Alexander, J., McGregor, J. \& Ranger, T. (2000). Violence and memory: One hundred years in the 'darkforests' of Matabeleland. Oxford: James Currey.

Andersson, J. (2007). How much did property rights matter? Understanding food insecurity in Zimbabwe: A critique of Richarson. African Affairs, 106(425), 68190.

Bernstein, H. (2004). 'Changing before our very eyes': Agrarian question and the politics of land in capitalism today.Journal of Agrarian Change, 4(1\&2), 190-225.

Boehm, C. (2003). The social life of fields: Labour markets and agrarian change in Lesotho. Paideusis: Journal for Interdisciplinary and Cross-Cultural Studies, 3, 120.

Bush, R. \& Cliffe, L. (1984). Agrarian policy in migrant labour societies: Reform or transformation in Zimbabwe? Review of African Political Economy, 11, 77-94

Chaumba, J., Scoones, I. \& Wolmer, W. (2003). From jambanja to planning: The reassertion of technocracy in south-eastern Zimbabwe? Journal of Modern African Studies, 41 (4), 533-554

Cheater, A. (1990). The ideology of 'communal' land tenure in Zimbabwe: Mythogenesis enacted? Africa, 60 (2), 188-206.

Chimhowu, A., \& Hulme, D. (2006). Livelihood dynamics in planned and spontaneous resettlement in Zimbabwe: Converging and vulnerable. World Development, 34 (4), 728-750.

Cordell, D. D., Gregory, J. W. \& Piché, V. (1996). Hoe and wage. A social history of a circular migration system in west Africa. Boulder, CO: Westview Press.

Coudere, H. \& Marijsse, S. (1988). Rich and poor in Mutoko Communal Area. Zimbabwe Journal of Economics, 2(1), 1-25.

Cousins, B, \& Scoones, I. (2010) Contested paradigms of 'viability' in redistributive land reform: perspectives from southern Africa. The Journal of Peasant Studies, 37:1, 31-66.

Hughes A.J.B. (1974). Development in Rhodesian Tribal Areas. Salisbury: Tribal Areas of Rhodesia Research Foundation.

Leduka, R.C. (2004). Explaining informal land delivery systems and institutions in African cities: Conceptual framework and emerging evidence. Paper presented at a workshop on The perpetuating challenge of informal settlements. University of the Witwatersrand, 8-10 November.

Mohamed-Katerere, J. (2003). Participatory natural resources management in the communal lands of Zimbabwe: What role for customary law? African Studies Quarterly, 5(3), 115-128.

Mphale, M. M., Rwambali, E. G. \& Makoae, M. G. (2002). HIV/AIDS and its impacts on land tenure and livelihoods in Lesotho. ECRA Consulting: Maseru.

Nyambara, P.S. (2001). Immigrants, "traditional" leaders and the Rhodesian state: The power of "communal" land tenure and the politics of land acquisition in Gokwe, Zimbabwe, 1963-1979. Journal of Southern African Studies, 27(4), 771-91

O'Flaherty, M. (1998). Communal tenure in Zimbabwe: Divergent models of collective landholding in the communal areas. Africa, 68(4), 537-557. 
Potts, D. (2000). Worker-peasants and farmer-housewives in Africa: The debate about 'committed' farmers, access to land and agricultural production. Journal of Southern African Studies, 26(4), 807-32.

Potts, D. \& Mutambirwa, C. (1990). Rural-urban linkages in contemporary Harare: Why migrants need their land. Journal of Southern African Studies, 16(4), 677-698.

Pule, N.W. \& Thabane, M. (2004). Lesotho's land tenure regimes: Experiences of rural communities and calls for land reform. The Journal of Modern African Studies, 42(2), 283-303.

Ranger, T. O. (1982). Tradition and travesty: Chiefs and the administration in Makoni District, Zimbabwe, 1960-80. Africa, 52(3), 20-41.

Quinlan, T.K.C. (1983). Transformation of land tenure in Lesotho. MA Dissertation, University of Cape Town, Cape Town.

Shipton, P. \& Goheen, M. (1992). Understanding African landholdings: Power, wealth and meaning. Africa, 62(3), 307-325.

Sperfeld, R. (2006). Decentralisation and the establishment of local government in Lesotho. Universität Potsdam.

Thebe, V. (2012). 'New realities' and tenure reforms: land-use in worker-peasant communities of south-western Zimbabwe (1940s-2006). Journal of Contemporary African Studies, 30(1), 99-117.

Thebe, V. (2017). Legacies of 'madiro'? Worker-peasantry, livelihood crisis and 'siziphile' land occupations in semi-arid north-western Zimbabwe. Journal of Modern African Studies, 55(2), 2001-224.

Weiner, D. \& Harris, T. (1991). Agricultural development in Zimbabwe: Transition in a labour reserve economy, in A. Seidman, K.W.C. Na Mwanza, N. Simelane and D. Weiner (eds.) (eds). Rethinking agricultural transformation in Southern Africa. Africa World Press, Trenton.

Weinrich, A.K.H. (1975). African farmers in Rhodesia: Old and new peasant communities in Karangaland. London: Oxford University Press.

UN-HABITAT. (2005). Land tenure, housing rights and gender in Lesotho. Nairobi: United Nations Human Settlement Programme (UN-HABITAT).

Wittmayer, J. (2007). Life projects, development and state: An anthopological study into land claims in Lesotho. MA Thesis, Vrije Universiteit, Amsterdam.

Yudelman, M. (1964). Africans on the land. Cambridge, Mass.: Harvard University Press. 